\title{
TINJAUAN IMPLEMENTASI FATWA DSN NO.25/DSN-MUI/III/2002 PADA PELAKSANAAN PENJUALAN BARANG GADAI YANG TIDAK DITEBUS DI BANK JATIM SYARIAH")
}

\author{
Khurin Fijria Nuzula \\ Program Studi S1 Ekonomi Islam_fakultas EKonomi dan Bisnis-Universitas Airlangga \\ Email: khurinfijria06@gmail.com \\ Irham Zaki \\ Departemen Ekonomi Syariah-Fakultas Ekonomi dan Bisnis-Universitas Airlangga \\ Email: irhamzaki0712@gmail.com
}

\begin{abstract}
:
The purpose of this research is to assess the compliance of the selling procedures for unredeemed pawn goods (Marhun) in accordance to the National Sharia Council's Fatwa No:25/DSN-MUI/III/2002 in Bank Jatim Syariah. The selling of unredeemed pawn goods (marhun) is analyzed from 4 aspects : (1) Maturity, (2) the execution of sale, (3) the result of the sale and (4) the excess or deficit from the result of the sale. This research adopts a qualitative approach with a case study methodology. The result of this research suggests that there is incompliance to the National Sharia Council's Fatwa No:25/DSN-MUI/III/2002 in the act of selling unredeemed pawn goods (marhun) by Bank Jatim Syariah, however this incompliance does not indicate any breach to the sharia rulings on sales and purchase.

Keywords : Pawning, Sale of Pawned Goods, National Sharia Council Fatwas, Bank Jatim Syariah
\end{abstract}

\section{PENDAHULUAN}

Gadai adalah suatu hak yang diperoleh oleh orang yang mempunyai piutang atas suatu barang bergerak. Barang bergerak tersebut diserahkan kepada orang yang berpiutang oleh seorang yang mempunyai utang atau orang lain atas nama orang yang mempunyai utang. Seorang yang berutang tersebut memberikan kekuasaan pada orang lain yang berpiutang untuk menggunakan barang bergerak yang telah diserahkan untuk melunasi utang apabila pihak yang berutang tidak dapat melunasi kewajibannya pada saat jatuh tempo. Gadai diatur dalam Buku II Titel 20 pasal 1150 sampai dengan pasal 1161 KUHPerdata. Menurut pasal 1150
KUHPerdata, pengertian gadai adalah suatu hak yang diperoleh seorang kreditor atas suatu barang bergerak yang bertubuh maupun tidak bertubuh yang diberikan kepadanya oleh debitor atau orang lain atas namanya untuk menjamin suatu utang (Sutedi, 2011:1). Islam membenarkan adanya praktik pegadaian yang dilakukan dengan cara-cara dan tujuan yang tidak merugikan orang lain. Pegadaian dibolehkan dengan syarat rukun yang bebas dari unsur-unsur yang dilarang dan merusak perjanjian gadai (Sutedi, 2011:13). Gadai syariah (Rahn) adalah menahan salah satu harta milik nasabah (rahin) sebagai barang jaminan (marhun) atas utang / pinjaman (marhun bih) yang diterimanya (Rais, 2005:38).

1) Jurnal ini merupakan bagian dari skripsi dari Khurin Fijria Nuzula, NIM : 041114122 , yang diuji pada 29 Januari 2016 
Khurin Fijia Nuzula, et al/Jurnal Ekonomi Syariah Teori dan Terapan Vol. 3 No. 5 Mei 2016: 418-429; TINJAUAN IMPLEMENTASI FATWA DSN NO.25/DSN-MUI/III/2002 PADA PELAKSANAAN PENJUALAN BARANG GADAI YANG TIDAK DITEBUS DI BANK JATIM SYARIAH

Pada dasarnya gadai menurut Islam hukumnya adalah boleh (jaiz). Dalam AlQur'an surat Al-Baqarah ayat 283 dijelaskan bahwa gadai pada hakikatnya merupakan salah satu bentuk dari konsep muamalah, dimana sikap menolong dan sikap amanah sangat ditonjolkan. Maka pada dasarnya, hakikat dan fungsi Pegadaian dalam Islam adalah sematamata untuk memberikan pertolongan kepada orang yang membutuhkan dengan bentuk marhun sebagai jaminan, dan bukan untuk kepentingan komersiil dengan mengambil keuntungan yang sebesar besarnya tanpa menghiraukan kemampuan orang lain (Rais, 2005:41).

Produk Rahn disediakan untuk membantu nasabah dalam pembiayaan kegiatan multiguna. Rahn sebagai produk pinjaman, berarti pegadaian syariah hanya memperoleh imbalan atas biaya administrasi, penyimpanan, pemeliharaan dan asuransi marhun. Produk rahn ini biasanya hanya digunakan bagi keperluan fungsi sosial-konsumtif seperti kebutuhan hidup, pendidikan dan kesehatan (Rais, 2005:42).

Seiring berkembangnya waktu kebutuhan masyarakat semakin meningkat dan beragam, sehingga dibutuhkan aliran dana yang cepat untuk memenuhinya. Terdapat beberapa upaya yang dilakukan masyarakat untuk mendapatkan dana tersebut, salah satunya dengan cara mengajukan pembiayaan di bank syariah. Salah satu produk pembiayaan yang mengalirkan dana dengan cepat yaitu gadai (rahn), seperti fenomena yang menyatakan bahwa menjelang penerimaan peserta didik baru (PPDB) kantor pegadaian mulai banyak dikunjungi warga, rata-rata mereka menggadaikan perhiasan untuk menutupi biaya pendidikan (www.jawaban.com). Selain itu, orang menggadai barangnya seperti perhiasan emas untuk kebutuhan konsumtif (aceh.tribunnews.com). Oleh sebab itu, produk gadai pada bank syariah merupakan salah satu produk yang digemari oleh masyarakat.

Bank Jatim memiliki Unit Usaha Syariah yaitu Bank Jatim Syariah. Bank Jatim Syariah juga memiliki produk gadai (rahn). Bank Jatim Syariah dalam memberikan pinjaman harus ada benda jaminan dari nasabah berupa emas batangan atau perhiasan. Apabila pada saat jatuh tempo nasabah tidak dapat melunasi pinjamannnya, maka pihak Bank Jatim Syariah berhak melelang benda jaminan untuk melunasi utang nasabah tersebut sesuai dengan Standard Operational Procedur (SOP) gadai Bank Jatim Syariah.

Pelaksanaan penjualan barang gadai di bank syariah tidak terlepas dari aturan Dewan Syariah Nasional. Dewan Syariah Nasional (DSN) mengeluarkan fatwa sebagai bentuk dukungan terhadap pengembangan gadai syariah, yaitu Fatwa No.25/DSN-MUI/III/2002 tentang Rah. Terdapat aturan mengenai 
Khurin Fijia Nuzula, et al/Jurnal Ekonomi Syariah Teori dan Terapan Vol. 3 No. 5 Mei 2016: 418-429; TINJAUAN IMPLEMENTASI FATWA DSN NO.25/DSN-MUI/III/2002 PADA PELAKSANAAN PENJUALAN BARANG GADAI YANG TIDAK DITEBUS DI BANK JATIM SYARIAH

penjualan barang gadai didalamnya yaitu :

a. Apabila jatuh tempo, murtahin harus memperingatkan rahin untuk segera melunasi utangnya.

b. Apabila rahin tetap tidak dapat melunasi utangnya, maka marhun dijual paksa / dieksekusi melalui lelang sesuai syariah.

c. Hasil penjualan marhun digunakan untuk melunasi utang, biaya pemeliharaan dan penyimpanan yang belum dibayar serta biaya penjualan.

d. Kelebihan hasil penjualan menjadi milik rahin dan kekurangannya menjadi kewajiban rahin.

Dalam pelaksanaan penjualan barang gadai (marhun), fatwa Dewan Syariah Nasional itulah yang mendasari dan menjadi pedoman praktik gadai syariah baik di lembaga Pegadaian maupun di Bank Syariah. Dengan adanya fatwa tentang rahn, ternyata masih ada beberapa pendapat yang mengatakan bahwa penjualan barang gadai di perbankan syariah masih diragukan kepatuhannya terhadap aturan-aturan yang berlaku.

Berdasarkan latar belakang tersebut maka penulis tertarik untuk mengadakan penelitian dengan judul

"Kesesuaian Penjualan Barang Gadai (Marhun) yang Tidak Ditebus Berdasarkan Fatwa Dewan Syariah Nasional No:25/DSN-MUI/III/2002 Pada Bank Jatim Syariah".

\section{LANDASAN TEORI}

Rais (2005:126) menjelaskan bahwa menurut Pasal 1150 KUH Perdata pengertian gadai adalah Suatu hak yang diperoleh seorang kreditor atas suatu barang bergerak yang bertubuh maupun tidak bertubuh yang diberikan kepadanya oleh debitor atau orang lain atas namanya untuk menjamin suatu utang, dan yang memberikan kewenangan kepada kreditor untuk mendapatkan pelunasan dari barang tersebut lebih dahulu daripada kreditor-kreditor lainnya terkecuali biaya-biaya untuk melelang barang tersebut dan biaya yang telah dikeluarkan untuk memelihara benda itu, biaya-biaya mana harus didahulukan. Gadai merupakan suatu transaksi dengan cara menangguhkan suatu barang yang memiliki nilai agar dapat menjadi jaminan untuk memperoleh utang (sejumlah vang), yang nantinya akan ditebus kembali sesuai kesepakatan antara pihak yang berutang dan pihak yang memberikan utang.

Gadai dalam figh disebut Ar-Rahn, yaitu suatu perjanjian untuk menahan suatu barang sebagai tanggungan utang. Dalam bahasa Arab Ar-Rahn disebut atstsubut wa ad-dawam yang berarti tetap dan kekal, makna dari tetap dan kekal adalah menahan yaitu menjadikan barang yang bersifat materi sebagai pengikat utang (Ali, 2008:1). Para ahli hukum mengemukakan pengertian gadai (rahn) sebagai berikut (Ali, 2008:2):

Ulama Syafi'iyah mengatakan bahwa rahn adalah menjadikan suatu barang yang biasa dijual sebagai jaminan utang dipenuhi dari harganya, bila yang 
Khurin Fijia Nuzula, et al/Jurnal Ekonomi Syariah Teori dan Terapan Vol. 3 No. 5 Mei 2016: 418-429; TINJAUAN IMPLEMENTASI FATWA DSN NO.25/DSN-MUI/III/2002 PADA PELAKSANAAN PENJUALAN BARANG GADAI YANG TIDAK DITEBUS DI BANK JATIM SYARIAH

berutang tidak sanggup membayar utangnya. Ulama Hanabilah mengatakan bahwa rahn adalah suatu benda yang dijadikan kepercayaan suatu utang, untuk dipenuhi dari harganya, bila yang berutang tidak sanggup membayar utangnya. Ulama Malikiyah mengatakan bahwa rahn adalah sesuatu yang bernilai harta (mutawamal) yang diambil dari pemiliknya untuk dijadikan pengikat atas utang yang tetap mengikat. Ahmad Azhar Basyir mengatakan bahwa rahn adalah perjanjian menahan suatu barang sebagai tanggungan utang, atau menjadikan sesuatu benda bernilai menurut pandangan syara' sebagai tanggungan marhun bih, sehingga dengan adanya tanggungan utang itu seluruh atau sebagian utang dapat diterima. Muhammad Syafi'i Antonio mengatakan bahwa rahn adalah menahan salah satu harta milik nasbah (rahin) sebagai barang jaminan (marhun) atas utang/pinjaman (marhun bih) yang diterimanya. Marhun tersebut memiliki nilai ekonomis, sehingga pihak yang menahan atau penerima gadai (murtahin) memperoleh jaminan untuk dapat mengambil kembali seluruh atau sebagian piutangnya.

Berdasarkan pengertian gadai syariah (rahn) menurut para ahli hukum Islam diatas, dapat disimpulkan bahwa gadai syariah (rahn) adalah praktik menjaminkan atau menyerahkan barang yang bernilai ekonomis untuk mendapatkan pinjaman financial sebesar prosentase tertentu dari standar nilai taksir yang ditetapkan oleh pemberi pinjaman. Penerima pinjaman wajib membayar biaya penjagaan barang gadai (marhun) sebanyak hari barang gadai dititipkan. Barang gadai dapat diambil kembali oleh pemiliknya jika ia telah melunasi pinjamannya.

$$
\text { Hukum munculnya gadai syariah }
$$
(rahn) tidak semata-mata berasal dari diperbolehkannya karena merupakan salah satu sistem ekonomi yang memudahkan manusia. Dalam Al-Qur'an penjelasan mengenai rahn terdapat dalam surat Al-Baqarah ayat 283 yang berbunyi:

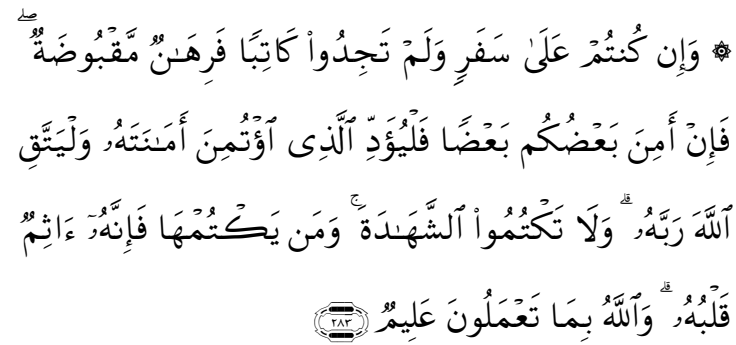

Artinya : Jika kamu dalam perjalanan (dan bermu'amalah tidak secara tunai) sedang kamu tidak memperoleh seorang penulis, Maka hendaklah ada barang tanggungan yang dipegang (oleh yang berpiutang). akan tetapi jika sebagian kamu mempercayai sebagian yang lain, Maka hendaklah yang dipercayai itu menunaikan amanatnya (utangnya) dan hendaklah ia bertakwa kepada Allah Tuhannya; dan janganlah kamu (para saksi) Menyembunyikan persaksian. dan Barangsiapa yang menyembunyikannya, Maka Sesungguhnya ia adalah orang yang berdosa hatinya; dan Allah Maha mengetahui apa yang kamu kerjakan. (Departemen Agama RI, 2010:42)

Ayat tersebut menjelaskan bahwa gadai pada hakikatnya merupakan salah satu bentuk dari konsep muamalah, 
Khurin Fijia Nuzula, et al/Jurnal Ekonomi Syariah Teori dan Terapan Vol. 3 No. 5 Mei 2016: 418-429; TINJAUAN IMPLEMENTASI FATWA DSN NO.25/DSN-MUI/III/2002 PADA PELAKSANAAN PENJUALAN BARANG GADAI YANG TIDAK DITEBUS DI BANK JATIM SYARIAH

dimana sikap menolong dan sikap amanah sangat ditonjolkan. Maka pada dasarnya, hakikat dan fungsi Pegadaian dalam Islam adalah semata-mata untuk memberikan pertolongan kepada orang yang membutuhkan dengan bentuk marhun sebagai jaminan, dan bukan untuk kepentingan komersiil dengan mengambil keuntungan yang sebesar besarnya tanpa mengjiraukan kemampuan orang lain (Rais, 2005:41). Syaikh Muhammad Ali As-Syais dalam Rais (2005:43) berpendapat bahwa ayat tersebut merupakan petunjuk merepakan prinsip kehati-hatian bila melakukan transaksi utang-piutang mengunakan jangka waktu tertentu dengan menjaminkan sebuah barang kepada orang yang berpiutang (rahn). Menurut Rais (2005:117), rahn memiliki peranan yang besar dalam kehidupan masyarakat khususnya untuk golongan menengah kebawah. Rahn dapat digunakan untuk menggerakkan usaha ekonomi kecil dan menengah agar bisa lebih berkembang, sehingga perekonomian secara makro dan mikro dapat mengalami peningkatan.

Berdasarkan pengertian rahn diatas dapat disimpulkan bahwa terdapat barang yang ditangguhkan untuk dijadikan sebagai jaminan (marhun), pihak yang menahan (murtahin) dan peminjam (rahin). Peminjam menangguhkan barangnya yang bernilai ekonomis kepada penangguh, barang tersebut harus bersifat materi agar apabila peminjam tidak dapat mengembalikan secara penuh penangguh dapat menjual barang tersebut agar dapat menutup utangnya, atau sesuai dengan perjanjian.

Sudarsono (2005:176) menjelaskan bahwa penjualan barang jaminan adalah upaya pengembalian uang pinjaman beserta jasa simpanan yang tidak dilunasi sampai batas waktu yang telah ditentukan. Penjualan barang gadai ini dilakukan setelah pemberitahuan dilakukan paling lambat 5 hari sebelum tanggal penjualan, melalui :

a. Surat pemberitahuan ke masingmasing alamat.

b. Dihubungi melalui telepon.

c. Papan pengumuman yanga da di kantor cabang, informasi di kantor kelurahan/kecamatan untuk cabang di daerah.

Apabila setelah penjualan dilakukan pegadaian syariah, ada kelebihan hasil penjualan barang gadai maka :

a. Uang kelebihan hasil penjualan barang gadai milik nasabah

b. Nasabah dapat meminta vang kelebihan ini ke Kantor Cabang Unit Layanan Gadai Syariah setempat.

c. Bila dalam 1 tahun tidak diambil, vang tersebut akan disalurkan ke lembaga ZIS

Sedangkan menurut Rais (2005:94) apabila rahin tidak dapat melunasi marhun bih-nya kepada murtahin, maka murtahin berhak untuk melelang/menjual marhun pada saat jatuh tempo. 
Khurin Fijia Nuzula, et al/Jurnal Ekonomi Syariah Teori dan Terapan Vol. 3 No. 5 Mei 2016: 418-429; TINJAUAN IMPLEMENTASI FATWA DSN NO.25/DSN-MUI/III/2002 PADA PELAKSANAAN PENJUALAN BARANG GADAI YANG TIDAK DITEBUS DI BANK JATIM SYARIAH

$$
\text { Sutedi (2011:137) menjelaskan }
$$

bahwa, berdasarkan Kep. Menteri Keuangan RI No. 337/KMK. 01/2000 Bab. 1, Ps. 1

Lelang adalah penjualan barang yang dilakukan di muka umum termasuk melalui media elektronik dengan cara penawaran lisan dengan harga yang semakin meningkat atau harga yang semakin menurun dan atau dengan penawaran harga secara tertulis yang didahului dengan usaha mengumpulkan para peminat.

Menurut Sutedi (2011:203), pada pegadaian syariah, pelelangan dilaksanakan apabila sampai batas waktu yang telah ditetapkan penerima gadai (rahin) masih tidak dapat melunasi uang pinjamannya (marhun bih), maka akan dilakukan proses pelelangan barang gadai atau jaminan (marhun) dengan prosedur sebagai berikut :

1. Satu minggu sebelum pelelangan barang gadai (marhun) dilakukan, pihak pegadaian akan memberitahukan penerima gadai (rahin) yang barang gadai atau jaminan (marhun) akan di lelang.

2. Ditetapkannya harga pegadaian pada saat pelelangan.

3. Hasil pelelangan akan digunakan untuk biaya penjualan dari harga penjualan, biaya pinjaman dan sisa akan dikembalikan kepada nasabah (rahin).

4. Sisa kelebihan (Uang kelebihan) yang tidak diambil oleh nasabah (rahin) akan diserahkan kepada Badan Amil
Zakat (BAZ) atau Lembaga Amil Zakat (LAZ) yang terskreditasi.

Apabila terdapat persyaratan menjual marhun pada saat jatuh tempo, ini dibolehkan dengan ketentuan sebagai berikut:

1. Murtahin harus terlebih dahulu mencari tahu keadaan rahin (penyebab belum melunasi utangnya).

2. Dapat memperpanjang tenggang waktu pembayaran.

3. Apabila murtahin benar-benar membutuhkan vang dan rahin belum melunasi marhun bih-nya, maka murtahin boleh memindahkan barang gadai kepada murtahin lain dengan seizin rahin.

4. Apabila ketentuan tersebut tidak terpenuhi, maka murtahin boleh menjual marhun dan kelebihan yangnya dikembalikan kepada rahin

5. Apabila hasil penjualan marhun lebih kecil dari jumlah marhun bih-nya, maka rahin harus menambah kekurangannya tersebut.

Definisi lelang dapat disamakan (diqiyaskan) dengan jual beli dimana ada pihak penjual dan pembeli. Di mana pegadaian dalam hal ini sebagai pihak penjual dan masyarakat yang hadir dalam pelelangan tersebut sebagai pihak pembeli. Jual beli tertulis dalam Q.S AlBaqarah 275 :

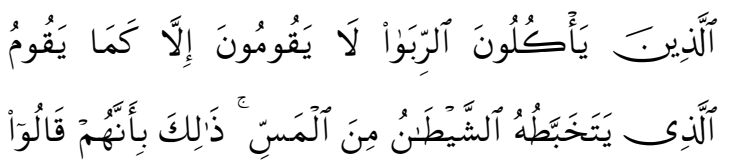


Khurin Fijia Nuzula, et al/Jurnal Ekonomi Syariah Teori dan Terapan Vol. 3 No. 5 Mei 2016: 418-429; TINJAUAN IMPLEMENTASI FATWA DSN NO.25/DSN-MUI/III/2002 PADA PELAKSANAAN PENJUALAN BARANG GADAI YANG TIDAK DITEBUS DI BANK JATIM SYARIAH

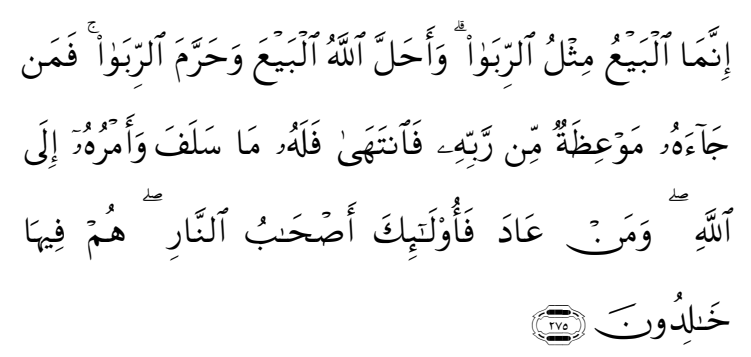

Artinya: "Orang-orang yang Makan (mengambil) riba tidak dapat berdiri melainkan seperti berdirinya orang yang kemasukan syaitan lantaran (tekanan) penyakit gila. Keadaan mereka yang demikian itu, adalah disebabkan mereka berkata (berpendapat), Sesungguhnya jual beli itu sama dengan riba, Padahal Allah telah menghalalkan jual beli dan mengharamkan riba. orang-orang yang telah sampai kepadanya larangan dari Tuhannya, lalu terus berhenti (dari mengambil riba), Maka baginya apa yang telah diambilnya dahulu (sebelum datang larangan); dan urusannya (terserah) kepada Allah. orang yang kembali (mengambil riba), Maka orang itu adalah penghuni-penghuni neraka; mereka kekal di dalamnya. (Departemen Agama Rl, 2010:41)

Ibnu Katsir dalam Yulianti (2015) menjelaskan bahwa dalam ayat tersebut Allah memerintahkan hambanya untuk beriman dan bertakwa melaui meninggalkan sesuatu yang dapat menjauhi hambanya dari keridhaan-Nya.

Dari kata "tinggalkan sisa riba" memeiliki makna tinggalkan hartamu yang merupakan kelebihan dari pokok yang harus dibayarkan oleh orang lain.

Penjualan dengan cara lelang disebut muzayadah. Penjualan seperti ini dibolehkan oleh agama Islam karena dijelaskan dalam satu hadits (Suhendi, 2014:86) :

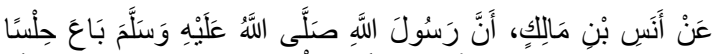

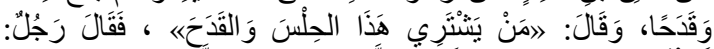

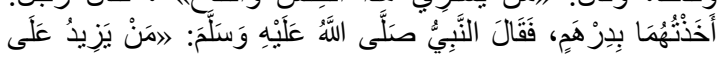

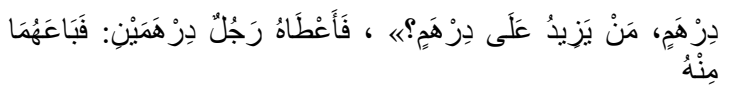

Dari Anas bin Malik bahwasanya: "Nabi sholallohu alaihi wasallam Menjual sebuah pelana dan sebuah mangkok air dengan berkata siapa yang mau membeli pelana dan mangkok ini? Seorang laki-laki menyahut; aku bersedia membelinya seharga satu dirham. Lalu Nabi berkata lagi, siapa yang berani menambahi? Maka diberi dua dirham oleh seorang lakilaki kepada beliau, lalu dijualah kedua benda itu kepada laki-laki tadi" (Riwayat Tirmidzi).

Penerapan gadai syariah (rahn) yang ada di Indonesia mengacu pada dasar hukum yang ditetapkan oleh Dewan Syariah Nasional Majelis Ulama Indonesia dalam Fatwa No: 25/DSNMUI/III/2002 tentang Rahn dan juga Fatwa No: 26/DSN-MUI/III/2002 tentang Rahn Emas. Fatwa tersebut menjelaskan tentang keputusan-keputusan yang telah disepakati oleh ulama Indonesia tentang Rahn, keputusan-keputusan yang diambil tersebut adalah:

a. Fatwa No: 25/DSN-MUI/III/2002

1. Hal-hal yang mendasari tentang hak dan kewajiban dari para murtahin (pemberi gadai) dan rahin (pemegang gadai). Diterangkan bahwa murtahin mempunyai hak untuk menahan marhun sampai rahin melunasi semua utangnya.

2. Pemanfaatan marhun oleh kedua belah pihak. Pada prinsipnya marhun dan manfaatnya tetap menjadi milik rahin, marhun juga tidak boleh dimanfaatkan oleh murtahin kecuali atas ijin dari rahin. 
Khurin Fijia Nuzula, et al/Jurnal Ekonomi Syariah Teori dan Terapan Vol. 3 No. 5 Mei 2016: 418-429; TINJAUAN IMPLEMENTASI FATWA DSN NO.25/DSN-MUI/III/2002 PADA PELAKSANAAN PENJUALAN BARANG GADAI YANG TIDAK DITEBUS DI BANK JATIM SYARIAH

3. Tentang pemeliharaan dan penyimpanan. Pemeliharaan dan penyimpanan marhun merupakan kewajiban rahin, namun dapat dipindah tangankan menjadi kewajiban murtahin atas kesepakatan bersama.

4. Tentang pembebanan biaya, dalam menentukan besarnya biaya pemeliharaan dan penyimpanan tidak boleh berdasarkan besarnya biaya peminjaman yang diajukan.

5. Tentang keputusan penjualan marhun, keputusan tersebut dilakukan apabila rahin tidak dapat melunasi utangnya. Namun tidak boleh langsung dijual, murtahin harus memperingatkan terlebih dahulu bahwa sudah jatuh tempo. Apabila rahin tetap tidak bisa melunasi utangnya, murtahin dapat menjual marhun sesuai dengan prinsip syariah yaitu dilakukan lelang syariah. Hasil dari lelang tersebut digunakan untuk melunasi utang rahin, apabila terdapat sisa maka menjadi hak rahin namun bila masih kurang maka rahin tetap berkewajiban untuk melunasi utangnya.

\section{METODE PENELITIAN}

\section{Pendekatan Penelitian}

Dalam penelitian ini, pendekatan yang di gunakan adalah kualitatif deskriptif. Penelitian ini menggunakan strategi studi kasus.

\section{Ruang Lingkup Penelitian}

Penelitian kualitatif menjadikan rumusan masalah sebagai fokus acuan untuk diteliti dan menentukan batasan ruang lingkup penelitian. Ruang lingkup penelitian ini fokus terhadap bagaimana kesesuaian penjualan barang gadai (marhun) yang tidak ditebus pada Bank Jatim Syariah terhadap fatwa Dewan Syariah Nasional No:25/DSNMUI/III/2002.

\section{Jenis dan Sumber Data}

Berdasarkan sumbernya, terdapat dua jenis sumber data yang dapat dikumpulkan oleh peneliti untuk mendukung penelitian yang dilakukan, yaitu :

1. Data pertama adalah melalui sumber primer, yaitu data yang diperoleh peneliti secara langsung dari informan utama dengan cara menanyakan sesuatu atau yang disebut dengan wawancara. Hasil wawancara dalam penelitian ini berupa informasi yang didapatkan dari informan terpilih yaitu: Officer gadai, Penyelia Supervisi Pembiayaan, nasabah gadai dan Dewan Pengawas Syariah (DPS) Bank Jatim Syariah.

2. Data yang kedua adalah melalui sumber sekunder, yaitu data yang berunsur nonmanusia sebagai data 
Khurin Fijia Nuzula, et al/Jurnal Ekonomi Syariah Teori dan Terapan Vol. 3 No. 5 Mei 2016: 418-429; TINJAUAN IMPLEMENTASI FATWA DSN NO.25/DSN-MUI/III/2002 PADA PELAKSANAAN PENJUALAN BARANG GADAI YANG TIDAK DITEBUS DI BANK JATIM SYARIAH

pendukung penelitian, data yang dimaksud adalah datadata yang bersifat dokumen. Penggunaan dokumen yang paling penting adalah mendukung dan menambah bukti dari sumber-sumber lain, seperti memverifikasi ejaan dan berbagai teks atas orang atau organisasi yang bersangkutan, menambah rincian spesifik lainnya, dan intervensi-intervensi tertentu. Dokumen tersebut berupa Fatwa Dewan Syariah Nasional No:25/DSN-MUI/III/2002

mengenai rahn, Standard Operational Procedur (SOP). Data sekunder juga diperoleh dari buku-buku yang membahas gadai syariah (rahn), jurnal dan artikel-artikel lainnya tentang rahn.

\section{Teknik Penentuan Informan}

Penentuan informan dalam penelitian ini menggunakan teknik Purposive Sampling atau sampling bertujuan. Purposive Sampling adalah suatu strategi jika seseorang menginginkan agar dapat memahami sesuatu mengenai kasus - kasus terpilih tertentu tanpa membutuhkan (atau berhasrat) untuk menggeneralisasi kepada semua kasus seperti itu. Informan yang dibutuhkan adalah owner atau pemilik usaha dan karyawan yang berhubungan langsung dengan pelanggan.

\section{Teknik Keabsahan Data}

Penelitian ini menggunakan teknik triangulasi dalam pemeriksaan keabsahan data. Terdapat tiga teknik triangulasi yakni triangulasi sumber, triangulasi teknik dan triangulasi waktu. Triangulasi yang digunakan dalam penelitian ini adalah triangulasi sumber yakni dengan cara membandingkan dan mengecek informasi yang di peroleh. Serta triangulasi teknik yakni dengan cara mengkroscek data yang didapat dari informan-informan terpilih dengan bukti-bukti yang ada. Peneltian ini melakukan pengecekan ulang sumber dilakukan dengan jalan membandingkan hasil wawancara dengan isi suatu dokumen yang berkaitan.

\section{Teknik Analisis Data}

Setelah dilakukan pengumpulan data dengan menggunakan pendekatan di atas, kemudian dilakukan teknik analisis data. Analisis data dilakukan agar hasil yang di peroleh dapat mudah dibaca dan dipahami sebagai cara untuk menyelesaikan permasalahan penelitian. Teknik analisis data yang digunakan dalam penelitian ini menggunakan teori milik Miles dan Huberman dalam Yin (2014) yang berjudul Studi Kasus Desain dan Metode yang terdiri dari tiga proses:

1. Data Reduction (Reduksi Data) 
Khurin Fijia Nuzula, et al/Jurnal Ekonomi Syariah Teori dan Terapan Vol. 3 No. 5 Mei 2016: 418-429; TINJAUAN IMPLEMENTASI FATWA DSN NO.25/DSN-MUI/III/2002 PADA PELAKSANAAN PENJUALAN BARANG GADAI YANG TIDAK DITEBUS DI BANK JATIM SYARIAH

Reduksi data adalah proses pemilihan, pemusatan perhatian pada penyederhanaan, pengabstrakan dantransformasu data kasar yang muncul dari catatan-catatan tertulis di lapangan.

2. Data Display (Penyajian Data) Penyajian data dalam penelitian ini disajikan dalam bentuk teks naratif, bagan dan tabel yang didapat dari hasil pengumpulan data pada Bank Jatim Syariah.

3. Conclusion Drawing/Verification (Menarik Kesimpulan/Verifikasi)

Pada tahap ini, peneliti mencari pola, tema, hubungan, persamaan, hal-hal yang sering timbul, hipotesis dan sebagainya hingga memperoleh suatu kesimpulan. Kesimpulan tersebut harus di verifikasi selama penelitian berlangsung dengan berbagai cara agar kredibilitasnya dapat dipertanggungjawabkan. Verifikasi penelitian ini menggunakan triangulasi data melalui observasi langsung, wawancara, dan dokumentasi terkait dengan penjualan barang gadai (marhun) yang tidak ditebus di Bank Jatim Syariah.

Teknik analisis khusus digunakan dipergunakan sebagai bagian dari strategi umum. Teknik analisis data yang digunakan dalam penelitian ini adalah penjodohan pola. Pola terseut berdasarkan teori empiris yang yang telah dikemukakan pada bab 2 dan berdasarkan proporsisi yang telah dibuat terkait kesesuaian penjualan barang gadai (marhun) yang tidak ditebus berdasarkan fatwa DSN No.25/DSN-MUI/III/2002 di Bank Jatim Syariah.

\section{HASIL DAN PEMBAHASAN}

Penerapan gadai syariah (rahn) yang ada di Indonesia mengacu pada dasar hukum yang ditetapkan oleh Dewan Syariah Nasional Majelis Ulama Indonesia dalam Fatwa No: 25/DSNMUI/III/2002 tentang Rahn. Fatwa tersebut menjelaskan tentang keputusankeputusan yang telah disepakati oleh ulama Indonesia tentang Rahn. Berikut merupakan bentuk kesesuaian penjualan barang gadai (marhun) yang tidak ditebus berdasarkan fatwa DSN No.25/DSN-MUI/III/2002 di Bank Jatim Syariah:

1. Apabila jatuh tempo, Murtahin harus memperingatkan Rahin untuk segera melunasi utangnya. Pihak Bank Jatim Syariah selalu mengingatkan nasabah untuk pelunasan yaitu seminggu sebelum tanggal jatun tempo. Peringatan kepada nasabah disampaikan oleh officer gadai Bank Jatim Syariah melalui telepon maupun pesan singkat.

2. Apabila Rahin tetap tidak dapat melunasi utangnya, maka Marhun dijual paksa/dieksekusi melalui lelang sesuai syariah. Pada saat tiba tanggal jatuh tempo pelunasan sementara nasabah tidak mampu melunasi utangnya, pihak Bank Jatim Syariah 
Khurin Fijia Nuzula, et al/Jurnal Ekonomi Syariah Teori dan Terapan Vol. 3 No. 5 Mei 2016: 418-429; TINJAUAN IMPLEMENTASI FATWA DSN NO.25/DSN-MUI/III/2002 PADA PELAKSANAAN PENJUALAN BARANG GADAI YANG TIDAK DITEBUS DI BANK JATIM SYARIAH

melakukan penjualan barang gadai (marhun). Penjualan dilakukan lima hari setalah tanggal jatuh tempo. Penjualan yang dilakukan dengan cara penjualan di bawah tangan. Penjualan di bawah tangan yang dimaksud ialah menjual barang gadai (marhun) langsung kepada orang lain / toko emas yang sanggup membeli dengan harga yang sesuai dengan taksiran harga emas pada saat itu untuk melunasi utang nasabah. Penjualan bawah tangan memiliki pengertian nasabah menyetujui dam mengetahui pelaksanaan penjualan barang gadai (marhun). Penjualan di bawah tangan ini dilakukan di kantor Bank Jatim Syariah dimana nasabah dan pembeli barang gadai (marhun) bertemu dengan disaksikan officer gadai. Pada saat harga beli telah disetujui oleh nasabah, vang hasil penjualan langsung dimasukkan dalam rekening nasabah dan dipotong oleh pihak Bank Jatim Syariah sejumlah utang nasabah.

3. Hasil penjualan Marhun digunakan untuk melunasi utang, biaya pemeliharan dan penyimpanan yang belum dibayar serta biaya penjualan. Hasil penjualan barang gadai (marhun) digunakan Bank untuk melunasi utang sebesar pembiayaan yang diberikan berdasarkan taksiran harga emas ditambah dengan biaya pemeliharaan barang gadai yang belum dibayar serta biaya penjualan barang gadai (marhun) tersebut.

4. Kelebihan hasil penjualan menjadi milik Rahin dan kekurangannya menjadi kewajiban Rahin. Berdasarkan pengalaman penjualan barang gadai yang tidak ditebus di Bank Jatim Syariah, selama beroprasi selama kurang lebih lima tahun, belum pernah ada hasil penjualan barang gadai (marhun) yang tidak ditebus kurang / lebih kecil dari utang nasabah. Sehingga jika terdapat kelebihan dari penjualan barang gadai (marhun), maka Bank akan melimpahkan kelebihan dana tersebut ke rekening nasabah di Bank Jatim Syariah.

\section{SIMPULAN}

Berdasarkan pada analisis dan pembahasan yang dijelaskan dalam bab 4, maka didapatkan kesimpulan bahwa terdapat ketidaksesuaian penjualan barang gadai (marhun) di Bank Jatim Syariah dengan Fatwa Dewan Syariah Nasional No:25/DSN-MUI/III/2002 terkait dengan eksekusi penjualan barang gadai (marhun). Ketidaksesuaian berupa adanya pasal dalam Pedoman Pelaksanaan Pembiayaan Gadai Bank Jatim Syariah yang mengijinkan adanya proses penjualan tidak melalui lelang namun dijual di bawah tangan, dalam praktik penjualannya pun tidak pernah melakukan pelelangan pada barang gadai (marhun) yang tidak ditebus seperti yang disebutkan dalam Fatwa Dewan 
Khurin Fijia Nuzula, et al/Jurnal Ekonomi Syariah Teori dan Terapan Vol. 3 No. 5 Mei 2016: 418-429; TINJAUAN IMPLEMENTASI FATWA DSN NO.25/DSN-MUI/III/2002 PADA PELAKSANAAN PENJUALAN BARANG GADAI YANG TIDAK DITEBUS DI BANK JATIM SYARIAH

Syariah Nasional No.25/DSN-MUI/III/2002. Penjualan barang gadai (marhun) tersebut dianalisis dari 4 pola yaitu: (1) masa jatuh tempo, (2) eksekusi penjualan barang gadai (marhun), (3) hasil penjualan barang gadai (marhun), (4) kelebihan dan kekurangan hasil penjualan barang gadai (marhun).

\subsection{Saran}

Saran yang dapat diberikan berdasarkan hasil dari penelitian adalah:

1. Bagi Dewan Syariah Nasional Majelis

Ulama Indonesia

Memperjelas dan melengkapi mekanisme lelang atau memberikan alternatif penjualan barang gadai (marhun) yang tidak ditebus dengan cara selain lelang, dengan pertimbangan praktik di lapangan yang tidak memungkinkan untuk melakukan lelang guna mencapai kemaslahatan.

2. Bagi Bank Jatim Syariah

Pencatatan terkait jumlah nasabah yang tidak melunasi utangnya pada saat jatuh tempo setiap tahunnya agar diperbaiki. Pasal terkait penjualan barang gadai (marhun) yang tidak ditebus pada Pedoman Pelaksanaan Pembiayaan Gadai Bank Jatim Syariah serta praktik penjualan barang gadai (marhun) yang tidak ditebus harus disesuaikan dengan Fatwa Dewan Syariah Nasional No.25/DSN-MUI/III/2002.

\section{Bagi Peneliti Selanjutnya}

Diharapkan penelitian selanjutnya bisa mendapatkan informasi yang lebih mendalam terkait dengan data-data
Bank Jatim Syariah agar penelitian yang dilakukan selanjutnya dapat lebih informatif dan lebih baik.

\section{DAFTAR PUSTAKA}

Ali, Zainuddin. 2008. Hukum Gadai Syariah. Cet, 1. Jakarta: Sinar Grafika

Rais, Sasli. 2005. Pegadaian Syariah: Konsep dan Sistem Operasional. Jakarta: Universitas Indonesia

Sudarsono, Heri. 2005. Bank dan Lembaga Kevangan Syariah Deskripsi dan Ilustrasi. Cet, 3. Yogyakarta: EKONISIA

Suhendi, Hendi. 2014. Fiqih Muamalah. Cet, 9. Jakarta: Rajawali Pers

Sutedi, Adrian. 2011. Hukum Gadai Syariah. Cet, 1. Bandung: Alfabeta

Yin, Robert K. 2014. Studi Kasus: desain dan metode. Jakarta: Rajawali Press

Yulianti, Annisa . 2015. Kepatuhan Syariah Akad Rahn (Gadai) Emas Berdasarkan Fatwa Dewan Syariah Nasional Majelis Ulama Indonesia pada PT. Bank Pembiayaan Rakyat Syariah Karya Mugi Sentosa. Surabaya: Universitas Airlangga 